\title{
Black spruce growth and foliar nutrient responses to drainage and fertilization: Wally Creek, Ontario
}

\author{
by Brian E. McLaren ${ }^{1}$ and John K. Jeglum ${ }^{2}$
}

We report tenth-year growth and yield improvements in the Wally Creek area, an experimental, systematic drainage project established in 1984 and fertilized in 1986, in a forested Ontario peatland. We analyzed and compared results for dominant-codominant and intermediate black spruce in two site types. Response of trees to NPK-fertilization was more immediate than to drainage. Response to drainage took about five to seven years, whereas response to fertilization occurred earlier, from three to five years. Some indication of an asymmetric response, with larger trees experiencing higher growth increases, was observed for the OG 11 (Ledum) site type, while yield increases were potentially higher in the OG 12 (Alnus herb-poor) site type. Drainage was most effective in combination with fertilization. Consistent for both site types were increases in phosphorus associated with fertilization. The Wally Creek project is a benchmark in the analysis of growth and yield response from intensive peatland silviculture.

Key words: black spruce, drainage, fertilization, foliar analysis, growth response, growth and yield, Lake Abitibi Model Forest, Ontario, stem analysis
Ce rapport résume 20 ans de croissance et d'amélioration du rendement d'un projet expérimental de drainage systématique d'une tourbière forestière de l'Ontario, établi dans la région de Wally Creek en 1984 et fertilisé en 1986. Les auteurs ont analysé et comparé les résultats obtenus des épinettes noires de l'étage dominantcodominant et intermédiaire provenant de deux stations. Les réactions des arbres à une fertilisation NPK ont été plus immédiates que celles en fonction du drainage. Les réactions au drainage ont nécessité de cinq à sept ans avant d'être apparentes, tandis que les réactions à la fertilisation se sont produites plus tôt, entre trois et cinq ans après le traitement. Une certaine indication de réactions asymétriques, notamment chez les arbres plus gros enregistrant des accroissements plus importants de croissance, a été relevé dans la station de type OG 11 (Ledum), tandis que les accroissement du rendement ont été potentiellement supérieurs dans la station de type OG 12 (Alnus peu herbacée). Le drainage était le plus efficace en combinaison avec la fertilisation. Les accroissements pour les deux stations étaient uniformes au niveau du phosphore associé à la fertilisation. Le projet de Wally Creek constitue un jalon important de l'analyse des réactions de croissance et de rendement pour la sylviculture intensive des tourbières.

\section{Forest Drainage in Canada}

Forest drainage is an anachronism. Drainage to improve forest growth on wetlands, especially on peatland, was an established management technique in Russia and Fennoscandia in the early part of this century (Heikurainen 1964). For example, an estimated 10\% of the growth of all forests in Finland has been ascribed to improvement due to peatland drainage and fertilization (Päiväinen 1984). Owing to these increases, this forest technology was imported into Canada and used in trials in Newfoundland (Päiväinen and Wells 1977), Québec (Trottier 1984), northeastern Ontario (Haavisto 1984; Rosen 1989), and northern Alberta (Hillman 1987; Hillman et al. 1990). Prior to this time, North American references to forest wetland drainage projects are sporadic. Averell and McGrew (1929) described an increase in production 15 years following drainage for stands of black spruce (Picea mariana [Mill.] B. S. P.), tamarack (Larix laricina [Du Roi] K. Koch) and northern white cedar (Thuja occidentalis L.) in Minnesota. Other drainage projects have been reported in Wisconsin (Zon and Averell 1929), Michigan (LeBarron and Netzel 1942; Satterland and Graham 1957), and Ontario (Stanek 1968; Payandeh 1973a, 1973b). Once touted as a sil-

\footnotetext{
${ }^{1}$ School of Forestry and Wood Products, Michigan Technological University, 1400 Townsend Drive, Houghton, MI 49931 (USA).

Current address: Government of Newfoundland \& Labrador, Department of Forest Resources and Agrifoods, Inland Fish and Wildlife Division, P.O. Box 8700, Bldg. 810, Pleasantville, St. John's, NF, A1B 4J6 (Canada), Tel. (709) 729-2541, FAX (709) 729-6629, email bmclaren@ wild.dnr.gov.nf.ca. ${ }^{2}$ Forest Peatland Science Section, Swedish University of Agricultural Sciences, S-901 83, Umeå (Sweden).
}

vicultural tool for use in large expanses of Canada's boreal forest (Stanek 1977; Päiväinen 1984; Rosen 1986; Haavisto and Jeglum 1991), forest drainage in Canada is currently out of favour in light of a new understanding of sustainability, identified in the Montreal Process, which emphasizes natural regeneration processes (Canadian Forest Service 1995).

Nonetheless, a report on the Wally Creek Area Forest Drainage Project in the northeastern Ontario Claybelt is now timely. Growth and yield in the Wally Creek area, near Cochrane, Ontario, is suited to long-rotation black spruce silviculture (MacLean and Bedell 1955). Because the Canadian forest industry relies heavily on black spruce for

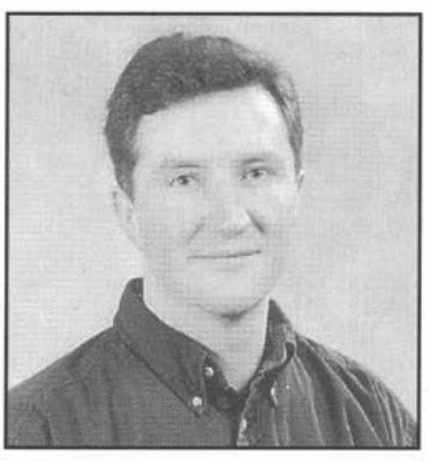
pulpwood, and because $50 \%$ of the forested land in Ontario dominated by black spruce is on peatland (Ketcheson and Jeglum 1972), the opportunity to test shortened harvest rotations by drainage and fertilization was the justification for the Wally Creek project. Shorter rotations are not just an economic 
benefit related to wood supply, but can reduce environmental and economic costs associated with harvesting and transporting wood in remote areas, with increasingly longer distances from existing pulp mills. The experiment, implemented in 1984, is now part of the Lake Abitibi Model Forest, and serves as an historic test case to document growth responses, environmental impacts, and economics of forest drainage (Jeglum 1991b).

In Fennoscandian countries, it takes three to four years for Scots pine (Pinus sylvestris L.) to adjust and stabilize at a new level of periodic increment, while for Norway spruce (Picea abies [L.] Karst.), it takes six to seven years (Heikurainen and Kuusela 1962; Laine and Starr 1979). Analyses of other drainage projects in North America (e.g. Payandeh 1973a; Weetman 1975; Dang and Lieffers 1989) indicate that growth improvements from drainage, usually of black spruce, begin as early as six years following treatment. This paper elaborates significantly on previous reports of growth and yield improvements in the Wally Creek project (Sundström 1992a, 1992b; Sundström and Jeglum 1992). Because some assessment attempts relied on field mensuration (Sundström 1992a; McLaren and Jeglum 1995), they were confounded by measurement errors for slow-growing black spruce. This paper analyzes volume growth using increment cores and destructive samples, and considers changes in foliar nutrient concentrations in drained and fertilized plots sampled ten years following establishment of the Wally Creek project. The goals of this assessment are to describe and explain wood volume growth increases associated with drainage and fertilization trials, alone and in combination, at Wally Creek.

\section{The Wally Creek Case Study, Ontario}

An area of about 300 ha of uneven-aged peatland forest, developed from advanced growth 55 years after a horse-logging operation, was systematically drained in November 1984. About $30 \mathrm{~km}$ east of Cochrane, Ontario $\left(49^{\circ} \mathrm{N}, 80^{\circ} 40^{\prime} \mathrm{W}\right)$, this area is in the Wally Creek watershed, which is a second-order tributary of the Abitibi River (Fig. 1). The surrounding lowland forest consists almost entirely of black spruce, with minor components of tamarack and balsam fir (Abies balsamea [L.] Mill.), $75 \%$ of which occurs on poorly-drained organic soils with $>40 \mathrm{~cm}$ peat thickness (Table 1). Further details on the vegetation in the area can be found in Jeglum (1991a) and Jeglum and $\mathrm{He}$ (1995).

Response to forest drainage is based on the principle that soil aeration will increase nutrient supply and decrease belowground competition for trees in waterlogged, organic site types (Rothwell et al. 1996). The procedure involves the construction of lateral ditches, which feed into collector ditches and ultimately into natural stream courses (Figs. 1,2). Further technical details can be found in Rosen (1989). Anoxic soils and a growing season length of about 160 days severely limit tree growth in the Wally Creek area (MacLean and Bedell 1955). Further climatic data for the study area can be found in Berry (1991) and Sundström (1992a). Drainage of the area, consisting mainly of the organic types OG 11 and OG 12 (Jones et al. 1983; Table 1), almost immediately increased soil temperature and aeration (Rothwell 1988), especially near ditches where water-table drawdown was highest (Berry and Jeglum 1991a). The Wally Creek drainage trial used a tracked vehicle with a large, contoured bucket to

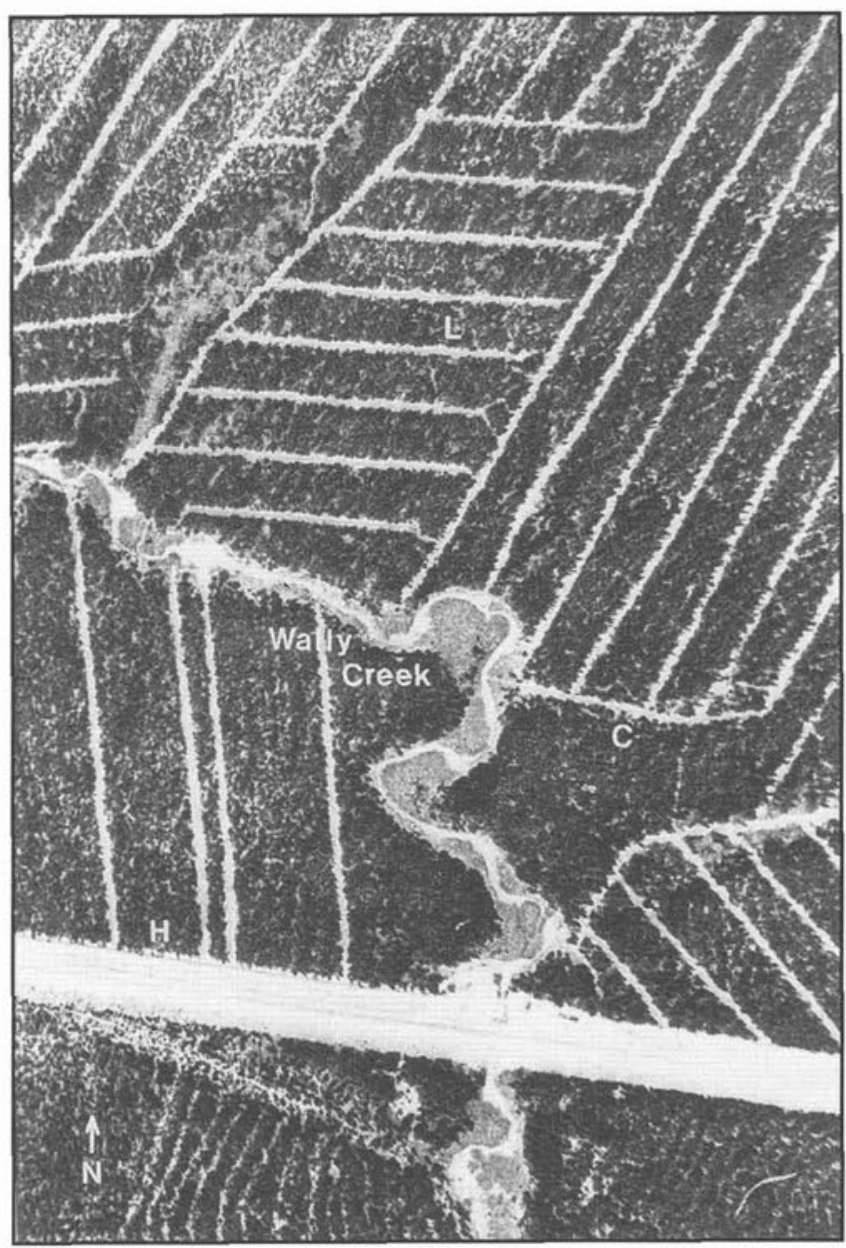

Fig. 1. Portion of the study area, showing lateral (L) and collector (C) ditches, draining into a natural water course (Wally Creek). The area is divided by a secondary highway $(\mathrm{H})$, south of which several control (undrained) plots were established. Note the horse-logging trails in the second-rotation forest south of the highway. Ditch spacing in the northern portion of the photograph is about $40 \mathrm{~m}$, providing an indication of scale.

construct $87 \mathrm{~km}$ of ditches, about $90 \mathrm{~cm}$ deep, with excavated peat mounds placed along ditch edges and a lateral ditch spacing of 30-40 m (Fig. 2). The vehicle, a Swedish Lännen S-10, was designed for commercial operations (Härkönen 1986). Later trials in Alberta (Hillman et al. 1990) used the same technology.

\section{Experimental Design, 1985-1986}

Study plots in the Wally Creek project were located in drained and undrained areas in four site types (Table 1). This paper mainly considers the better growing organic types, OG 11 (Ledum) and OG 12 (Alnus herb-poor). Drained plots were subdivided into mid-strip (DM) areas, $>7.5 \mathrm{~m}$ from an adjacent ditch, and near-ditch (DN) subplots, located up to a maximum distance of $7.5 \mathrm{~m}$ from ditch edges. DN subplots experienced more water-table drawdown (Berry and Jeglum 1991a), higher soil temperature increases, and enhanced fertilization effects from the peat mounds than DM subplots (Rothwell 1988). In every drained and undrained, control (UC) plot, there was a nested, fertilized subplot in addition to permanent monitoring 


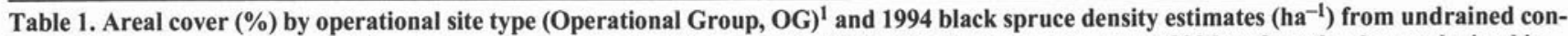
trol (UC), drained mid-strip (DM) and drained near-ditch (DN) plots in the Wally Creek study area. About 300 ha of peatland were drained in 1984, mostly in OG 11 and OG 12. Dominant-codominant trees are defined as $>9.9 \mathrm{~m}$ height and $>10.9 \mathrm{~cm}$ DBH, intermediate trees as $7.5-9.9 \mathrm{~m}$ height and 8.0-9.9 cm DBH. Mean sample plot size and replication are as follows: OG 8, UC, $433 \mathrm{~m}^{2}, n=1, \mathrm{DM}, 262 \mathrm{~m}^{2}, n=7, \mathrm{DN}, 132 \mathrm{~m}^{2}, n=7$; OG 11, UC, $400 \mathrm{~m}^{2}, n=6, \mathrm{DM}, 233 \mathrm{~m}^{2}, n=14, \mathrm{DN}, 153 \mathrm{~m}^{2}, n=14 ;$ OG 12, UC, $398 \mathrm{~m}^{2}, n=8$, DM, $217 \mathrm{~m}^{2}, n=8, \mathrm{DN}, 163 \mathrm{~m}^{2}, n=8$.

\begin{tabular}{|c|c|c|c|c|c|c|c|c|c|}
\hline \multirow[b]{3}{*}{ OG } & \multirow[b]{3}{*}{ Identification } & \multirow{3}{*}{$\begin{array}{c}\begin{array}{c}\text { Peat } \\
\text { depth } \\
(\mathrm{cm})\end{array} \\
\end{array}$} & \multirow{3}{*}{$\begin{array}{l}\text { Areal } \\
\text { cover } \\
(\%)^{1}\end{array}$} & \multicolumn{6}{|c|}{ Black spruce density $\left(\mathrm{ha}^{-1}\right)$} \\
\hline & & & & \multicolumn{3}{|c|}{ Dom.-codominant } & \multicolumn{3}{|c|}{ Intermediate } \\
\hline & & & & UC & DM & DN & UC & DM & DN \\
\hline \multicolumn{10}{|l|}{ Mineral Types } \\
\hline 8 & Feathermoss-Sphagnum & $<40$ & 12 & 1180 & 1240 & 520 & 480 & 340 & 230 \\
\hline 9 & Conifer-Herb/Moss Rich & $<40$ & 8 & not sampled & & & & & \\
\hline \multicolumn{10}{|l|}{ Organic Types } \\
\hline 11 & Ledum & $40-100$ & 20 & 690 & 1040 & 570 & 1650 & 420 & 210 \\
\hline 12 & Alnus-Herb Poor & $40-100$ & 38 & 850 & 690 & 530 & 1140 & 360 & 150 \\
\hline 13 & Alnus-Herb Rich & $40-100$ & 2 & not sampled & & & & & \\
\hline 14 & Chamaedaphne & $>100$ & 16 & trees do not $\mathrm{c}$ & onform & ze defi & & & \\
\hline
\end{tabular}

${ }^{1}$ From Jones et al. (1983) and Ecological Services for Planning, Ltd. (1985).

subplots and destructive subplots that were not fertilized (Fig. 2). A manual application of $150: 100: 100 \mathrm{~kg} \mathrm{ha}^{-1}$ NPK urea-based commercial fertilizer was applied to fertilized subplots in July 1986. Plot replication and plot size are indicated in the caption accompanying Table 1, in Fig. 2, and in Sundström (1992a, 1992b). This paper reports analyses of growth occurring five years before, to ten growing seasons following, drainage (destructive sampling occurred in fall 1994) and fertilization (foliar sampling occurred in fall 1995).

\section{Tenth-Year Assessment, 1994-1995}

Data collection in this study was based on separate observations for dominant-codominant trees and intermediate trees, and all calculations were made for black spruce only. The reason for the size distinction is twofold. At present, except where forest stands are dense and suppressed, most fibre is obtained from trees $\geq 10 \mathrm{~m}$ height in the Claybelt (MacLean and Bedell 1955). To some extent, then, calculations for dominant-codominant trees answer the most relevant yield question. However, there is also indication that in some site types, intermediate trees may show the largest response to release from root competition (Heikurainen 1964; Sundström and Jeglum 1992). Therefore, asymmetry of the drainage response becomes a second relevant question. Size definitions, listed in the caption accompanying Table 1, were taken from Sundström (1992a). Tree response was not classified by age because of the difficulty of obtaining accurate ages of black spruce originating from advanced growth in peatland.

Black spruce stem densities were measured in 1994 in permanent plots of $400 \mathrm{~m}^{2}$ in the three site types and two size classes. At this time, tree losses due to ditch excavation or windfalls were tallied and recorded in Sundström (1992a) and McLaren and Jeglum (1995). Two increment cores were collected, one each from the north and south sides of stems at breast height on five trees in each size class, in each UC, DM and DN drained plot, and in fertilized and unfertilized subplots of the OG 11 and OG 12 site types. Cores were mounted, dried and sanded, and three five-year increments were measured from the cambium with a $40 \times$ binocular microscope $\left( \pm 10^{-5} \mathrm{~m}\right.$ precision). These increments were equivalent to three periods: pretreatment, 1980-1984; first five-year, post-treatment, 1985-1989; and second five-year, post-treatment, 1990-1994. The two posttreatment periods were compared in a repeated measures, splitplot analysis of variance (ANOVA), with drainage forming the main effect, and fertilization a nested effect. The 1990-1994 growth increment was also used to calculate an average, annual post-treatment wood volume yield by multiplying mean annual diameter at breast height (DBH) increment by standardized tree dimensions from Honer's equations for merchantable black spruce volume (Honer et al. 1983), and from mean stem densities in permanent plots of each of four treatments (undrained, unfertilized; undrained, fertilized; drained, unfertilized; and drained, fertilized).

Twenty destructive samples, representing five trees from the two size classes and the two fertilization subplots, were collected from one UC, one DM, and one DN plot in the OG 11 and in the OG 12 site types. These 120 stems were cut at ground level, and sectioned every $15 \mathrm{~cm}$ to $135 \mathrm{~cm}$, every $50 \mathrm{~cm}$ from $200 \mathrm{~cm}$ from the base to $200 \mathrm{~cm}$ from the top of the tree, and further every $15 \mathrm{~cm}$. Node height increments for the top of the stems, combined with ring counts and measurements for the last 25 years of growth on 4 radii of each cross-section were used with the tree-ring increment measurement (TRIM) system and stem analysis module (SAM) program to calculate volume increments and specific volume increments (SVI) for each tree. Specific volume increments represent the biological growth potential of conifers (Duff and Nolan 1957), and are annual volume increments corrected for tree size by dividing by the average cambial surface area during each growing season. Annual SVI in all trees was further corrected for variation, $\mathrm{w}_{\mathrm{i}}$, from mean SVI, $\mathrm{SVI}_{\mathrm{avg}}$, for the 15 -year period in undrained, unfertilized (UF) plots of the same site type, where $\mathrm{w}_{\mathrm{i}}=\left(\mathrm{SVI}_{\mathrm{UC}, \mathrm{UF}(\mathrm{i})}-\mathrm{SVI}_{\text {avg }}\right) / \mathrm{SVI}_{\text {avg }}$, for $\mathrm{i}=1$ to 15 , with the formula $S V I_{\text {corr, } x(i)}=S V I_{x(i)}-\left(1_{-}-w_{i}\right)$, where $x$ was unfertilized DM, DN, or any fertilized treatments. The variation, $\mathrm{w}_{\mathrm{i}}$, was as much as $\pm 32 \%$ in OG 11 and $\pm 35 \%$ in OG 12 . The correction flattened the growth curve for control trees, and removed the effect of climatic variation from the treatment effects (Weetman et al. 1995). Treatment effects were expected equally in the upper part as well as the merchantable part of stems (Sundström 1992a, Sundström and Jeglum 1992), so SVI ${ }_{\text {corr }}$ was chosen to represent effects equally throughout the stem. 


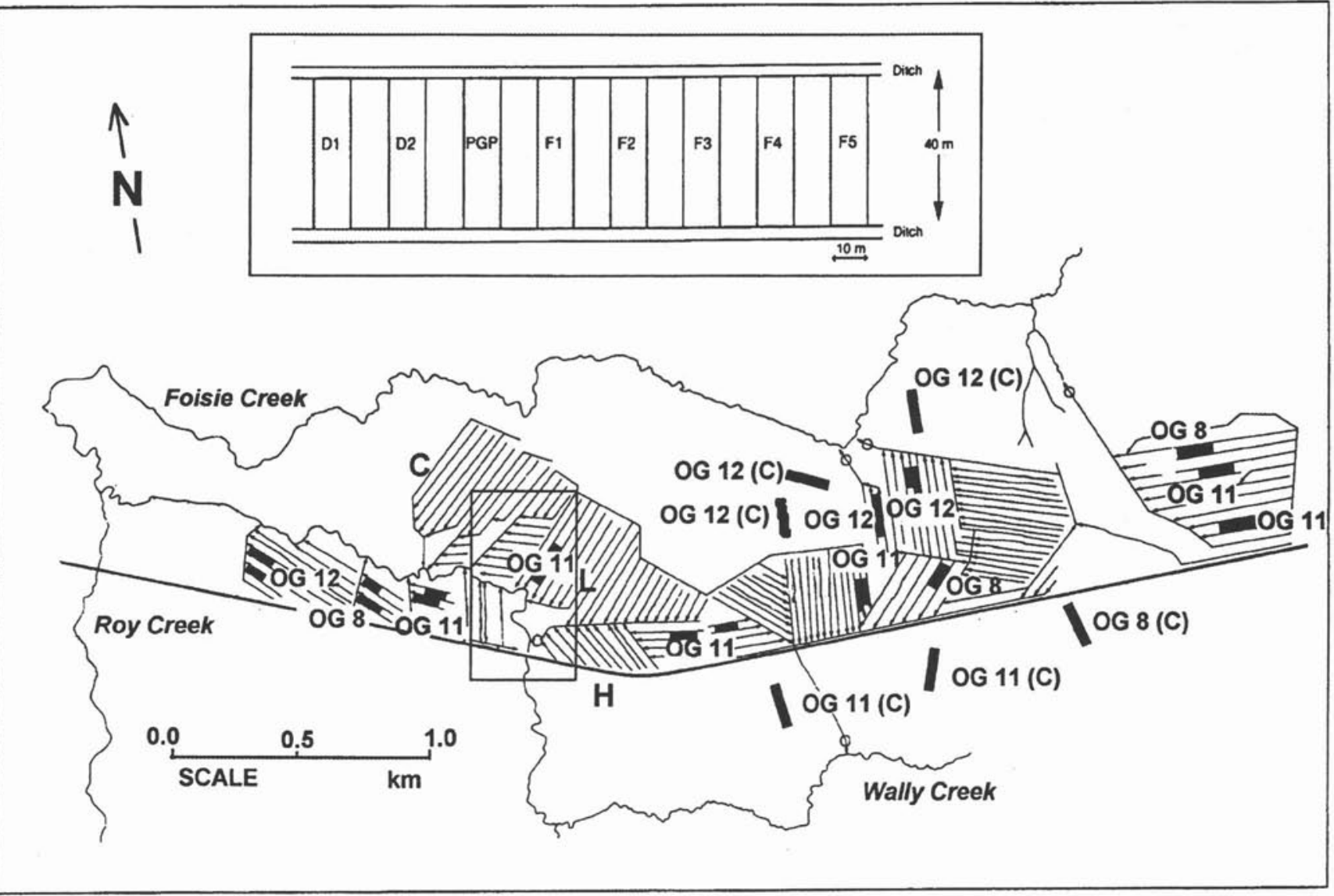

Fig. 2. Study area schematic, indicating lateral $(\mathrm{L})$ and collector $(\mathrm{C})$ ditches, the highway $(\mathrm{H})$ separating drained and undrained areas, and the location of the photographed area in Fig. 1 (box near centre of study area). Plot replicates are identified by operational group (OG 11 and OG 12; C indicates control areas). The insert shows subplot layout: stem densities were measured in the permanent growth plots (PGP); destructive samples and increment cores were taken from the D2 (unfertilized) and F2 (fertilized) subplots.

It follows from above that differences between dominant-codominant and intermediate trees owing to tree size alone are likewise reduced by SVI correction. All increment calculations were compared between plots; however, site types, size classes, and treatments were not replicated because of the time required for the more detailed stem analyses.

Current-year (1995) foliage samples were collected from the top third of the crown of five healthy, dominant-codominant black spruce stems in UC and DN, unfertilized and fertilized subplots. Samples were collected from at least three different lateral branches, in fall 1995. Samples from the same subplots were combined, and the oven-dry $\left(70^{\circ} \mathrm{C}\right)$ mass of 100 needles was measured. Samples were ground, homogenized, and analysed for $\mathrm{N}, \mathrm{P}, \mathrm{K}, \mathrm{Ca}$ and $\mathrm{Mg}$. Needle mass and nutrient concentrations were compared for each of the treatments in a fixed effects, unbalanced ANOVA.

\section{Growth and Yield Results}

Comparisons of tree density by size class show that the organic site types are typified by fewer large and more intermediate stems than the upland OG 8 site type (Table 1). Similarly, OG 11 stands are generally denser than OG 12 stands, particularly for trees in the intermediate size class. Variable ditch spacing, generally wider in OG 11 than in OG 12, accounts for a higher proportion of DM trees in OG 11. Therefore, near-ditch areas, DN, are expected by virtue of their comparable levels of drainage and fertilization to provide better comparisons of undrained to drained treatments between OG 11 and OG 12 . Similarly, when overall growth responses per plot are compared, there will probably be a slightly better response in OG 12 , owing to the slightly narrower ditch spacing and resulting enhanced growth in the DM position. Finally, growth improvements per tree are expected to be higher in the less dense OG 12 , because of reduced below-ground competition for nutrients, while the total response of trees in OG 11 is likely to be exaggerated owing to the denser stands.

The increment core measurements in this study provide the best comparison of treatment effects, because plot replication forms a complete ANOVA design (Table 2). Drainage is a significant effect in both tree size classes in OG 11, and in intermediate trees in OG 12. Fertilization has a consistent, significant effect in both size classes and site types, except that a drainage and fertilizer interaction occurs in intermediate trees in OG 12. This interaction is likely due to the less striking increase in growth rates in this size class with fertilizer alone, while drainage generally produces an additional increase to the fertilization effects in both site types (Fig. 3). In unfertilized, drained treatments, there seem to be no differences among the increment periods for the DM position, but there are clear differences for the $\mathrm{DN}$ position. This comparison indicates the 
Table 2. Repeated measures, split-plot analysis of variance tables for black spruce DBH increment measured from cores (Fig. 3), by size class and operational site type. Only the post-treatment periods, 1985-1989 and 1990-1994, are compared in the complete design. The OG 11 design is unbalanced (see Fig. 3 for plot replication)

\begin{tabular}{|c|c|c|c|c|c|c|c|}
\hline \multirow[b]{2}{*}{ Source of Variation } & \multirow[b]{2}{*}{ df } & \multicolumn{3}{|c|}{ Dom.-codom. trees } & \multicolumn{3}{|c|}{ Intermediate trees } \\
\hline & & $\begin{array}{c}\text { Mean } \\
\text { Square }\end{array}$ & $\mathbf{F}$ & p & $\begin{array}{c}\text { Mean } \\
\text { Square }\end{array}$ & $\mathbf{F}$ & p \\
\hline \multicolumn{8}{|l|}{ Operational Group 11} \\
\hline Drainage & 2 & 0.0074 & 18.53 & 0.0001 & 0.0033 & 6.21 & 0.0051 \\
\hline Plot & 11 & 0.0008 & 2.09 & 0.0501 & 0.0007 & 1.41 & 0.2157 \\
\hline Fertilizer & 1 & 0.0027 & 6.80 & 0.0136 & 0.0024 & 4.58 & 0.0399 \\
\hline Drainage $\times$ Fertilizer & 2 & 0.0001 & 0.27 & 0.7665 & 0.0000 & 0.03 & 0.9698 \\
\hline Time & 1 & 0.0047 & 11.61 & 0.0017 & 0.0038 & 7.25 & 0.0110 \\
\hline Drainage $\times$ Time & 2 & 0.0027 & 6.82 & 0.0033 & 0.0010 & 1.84 & 0.1741 \\
\hline Fertilizer $\times$ Time & 1 & 0.0006 & 1.45 & 0.2377 & 0.0005 & 1.02 & 0.3188 \\
\hline Drainage $\times$ Fertilizer $\times$ Time & 2 & 0.0001 & 0.20 & 0.8201 & 0.0001 & 0.15 & 0.8632 \\
\hline Error & 33 & 0.0004 & & & 0.0005 & & \\
\hline Total & 55 & & & & & & \\
\hline \multicolumn{8}{|l|}{ Operational Group 12} \\
\hline Drainage & 2 & 0.0024 & 2.65 & 0.0980 & 0.0069 & 18.50 & 0.0001 \\
\hline Plot & 6 & 0.0043 & 4.63 & 0.0052 & 0.0009 & 2.44 & 0.0668 \\
\hline Fertilizer & 1 & 0.0240 & 25.97 & 0.0001 & 0.0139 & 37.20 & 0.0001 \\
\hline Drainage $\times$ Fertilizer & 2 & 0.0024 & 2.63 & 0.0998 & 0.0026 & 6.84 & 0.0062 \\
\hline Time & 1 & 0.0045 & 4.89 & 0.0401 & 0.0044 & 11.92 & 0.0028 \\
\hline Drainage $\times$ Time & 2 & 0.0005 & 0.51 & 0.6100 & 0.0005 & 1.43 & 0.2662 \\
\hline Fertilizer $\times$ Time & 1 & 0.0013 & 1.40 & 0.2527 & 0.0010 & 2.68 & 0.1187 \\
\hline Drainage $\times$ Fertilizer $\times$ Time & 2 & 0.0002 & 0.16 & 0.8501 & 0.0000 & 0.03 & 0.9750 \\
\hline Error & 18 & 0.0009 & & & 0.0004 & & \\
\hline Total & 35 & & & & & & \\
\hline
\end{tabular}

greater effectiveness of drainage near the ditches, and a combined improved aeration and nutrient status near the ditches. In the ANOVA summary, the post-treatment repeated measures show consistent, significant differences (Table 2). These differences illustrate the delayed response of the full treatment effects in slow-growing black spruce.

Combining the DBH increment effects with the stem densities reported in Table 1, we summarize the treatment effects as resulting in the greatest yield improvement when drainage and fertilization are used in combination (Table 3 ). The wide ranges in this yield table are a result of the considerable between-plot variation in increment measurements. Nevertheless, the construction of $95 \%$ confidence intervals in Table 3 allows a reasonably high power of prediction for treatment effects even given natural spatial variation in growth. For example, the sum effect of drainage alone on yield from dominant-codominant trees in OG 11 is significant for the six- to ten-year, posttreatment period. The same comparison is not true for intermediate trees, nor for total merchantable volume, because of the predominance of intermediate trees in OG 11 stands. However, total volume yield is higher for OG 11 when drainage and fertilization were applied together relative to undrained, unfertilized plots. No significant treatment responses are distinguishable for OG 12 in the same period; nonetheless, the upper part of the ranges of calculations for this site type are almost always higher than the comparable ranges for OG 11 . This result is probably related to the lower density of trees overall in OG 12 for which improvements might have occurred, and at the same time, the greater relative number of $\mathrm{DN}$ trees in OG 12.

Specific volume increment (SVI) measures also demonstrated significant increases in growth related to drainage and fertilization (Fig. 4; note scale change). Annual SVI for domi- nant-codominant and intermediate trees were not different, so they were combined in the analysis. From UC fertilized plots, it is clear that fertilization produced a large growth increase, over twice the SVI of unfertilized controls. In the DM position for OG 11, only a weak growth response was achieved by drainage alone, but there was a modest response to fertilization. In the DM position for OG 12 , there was no drainage response for unfertilized trees, similar to OG 11 . In the $\mathrm{DN}$ position, both the unfertilized and fertilized trees yielded responses; in OG 11, the responses were similar, whereas in OG 12, the fertilized response was much greater than that of the unfertilized trees. The good response in both site types in the unfertilized plots could have been caused by drainage effects, such as increased aeration and greater effective rooting layer depth, combined with an additional fertilization effect of the richer peats and mineral soil in the spoil mounds along the ditches. The responses all seemed to drop in the second five-year, post-treatment period, both for unfertilized and fertilized trees. This change may reflect a decline in nutrient supply after the first flush of high nutrient availability.

Total yield is compared for the four treatments over the three periods of interest, and compared by site type in Fig. 5 . Uncorrected volume growth calculations are combined for both drained subplots and multiplied by mean stem densities in each treatment, analogous to the calculations in Table 3. Yield calculations for OG 11 trees are consistently higher than for OG 12 trees, except for the undrained, fertilized treatment. This result is due to the higher density in OG 11 plots (Table 1), and suggests that even though the per-tree treatment response may be higher in OG 12, the volume response is better for OG 11. However, if the density of trees in OG 12 increases after treatment, then this type would become more productive with time. More relevant to this study is the treatment response. 

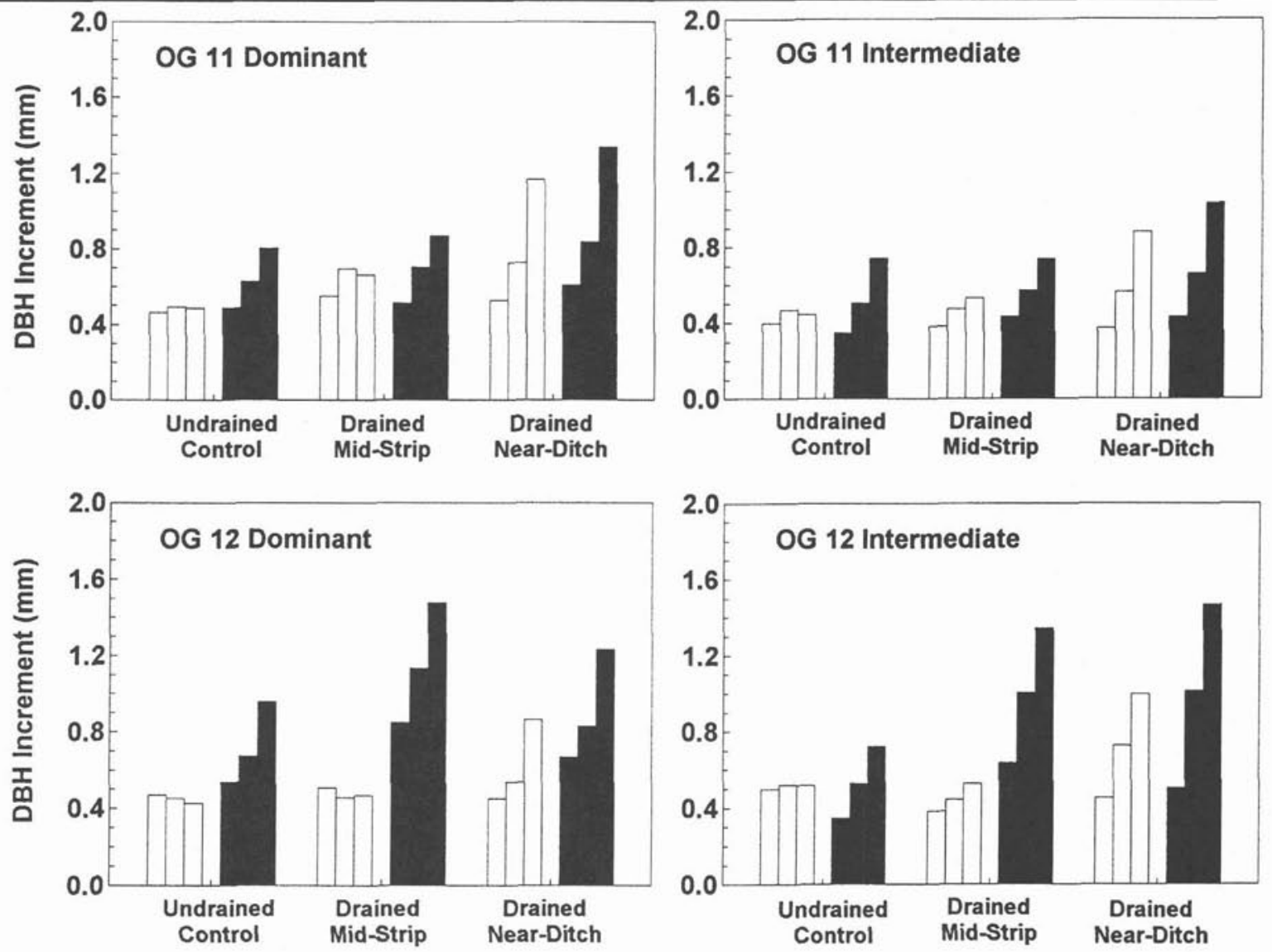

Fig. 3. Mean annual DBH increment (mm), from cores collected from black spruce in 2 operational site types and 2 size classes. Bar sequence represents 3 five-year periods relative to treatment effects: 1980-1984 (pre-treatment), 1985-1989 (first 5-year, post-treatment period, after drainage in 1985 and NPK fertilization in 1986), and 1990-1994 (second 5-year, post-treatment period). Mean increment by plot for the 3 periods is shown by location within the study area (undrained control, drained mid-strip, $15-20 \mathrm{~m}$ from adjacent ditches, and drained nearditch, $<7.5 \mathrm{~m}$ from an adjacent ditch), for unfertilized (open bars) and fertilized plots (filled bars). Replication for OG $11 \mathrm{control}, n=2, \mathrm{OG}$ 11 drained, $n=6$, OG 12 control, $n=3$, and OG 12 drained, $n=3$. See Table 2 for statistical comparison of these results.

Drainage and fertilization in combination further increase yield by a substantial factor, equivalent to about $200 \%$ improvement in the post-treatment period (Fig. 3). OG 12 shows an early increase during the first post-treatment period, which continues into the second period, whereas OG 11 shows an increase only during the second post-treatment period (Fig. 5).

\section{Foliar Analyses}

Foliar analyses were undertaken to (i) assist in interpretation of the growth and yield results, (ii) assess the potential for continued treatment effects based on nutritional differences in drained or fertilized plots, and (iii) understand which of several nutrients may have been limiting in the study area. Effects were investigated on needles of individual trees, such that increases in needle mass cannot be immediately interpreted as increases in photosynthetic biomass for treated stands as a whole. Likewise, changes in needle mass may affect interpretations of nutrient uptake at a stand scale. For stand-scale insights, estimates of needle number per tree would be required.

Treatment had no significant effect on needle mass in either site type (Tables 4, 5). A modest, but non-significant fertilization effect on needle mass in OG 12 (Table 4) strengthens our obser-
Table 3. Black spruce merchantable volume yield $\left(\mathrm{m}^{3} \mathrm{ha}^{-1} \mathrm{yr}^{-1}\right)$, for the second post-treatment period, 1990-1994 (6-10 years following drainage and 5-9 years following fertilization), by size class and operational site type. Ranges represent the $95 \%$ confidence interval for merchantable volume (Honer et al. 1983) calculated from mean DBH increment measured from cores (Fig. 3), mean annual height increment from destructively sampled trees, and mean stem densities in the study area (Table 1)

\begin{tabular}{lccc}
\hline \multirow{2}{*}{$\begin{array}{l}\text { Site type } \\
\text { / treatment }\end{array}$} & \multicolumn{3}{c}{ Merchantable volume yield $\left(\mathbf{m}^{\mathbf{3}} \mathbf{h a}^{-\mathbf{1}} \mathbf{y r} \mathbf{-}^{-\mathbf{1}}\right)$} \\
\cline { 2 - 4 } & Dom.-Codom. & Intermediate & Total \\
\hline Operational Group 11 & & & \\
Undrained, Unfertilized & $0.00-1.09$ & $0.00-1.40$ & $0.00-2.49$ \\
Undrained, Fertilized & $0.00-2.20$ & $1.27-1.40$ & $1.27-3.60$ \\
Drained, Unfertilized & $1.80-2.90$ & $0.33-0.52$ & $2.13-3.42$ \\
Drained, Fertilized & $2.69-3.18$ & $0.38-0.71$ & $3.07-3.89$ \\
Operational Group 12 & & & \\
Undrained, Unfertilized & $0.00-1.48$ & $0.00-1.15$ & $0.00-2.63$ \\
Undrained, Fertilized & $1.20-1.97$ & $0.74-1.19$ & $1.94-3.16$ \\
Drained, Unfertilized & $0.58-3.32$ & $0.27-0.64$ & $0.85-3.96$ \\
Drained, Fertilized & $0.00-7.24$ & $0.68-1.19$ & $0.68-8.43$ \\
\hline
\end{tabular}

vation that treatments in combination were most effective in this site type (Fig. 4). Consistent for both site types were increases in $\mathrm{P}$ associated with fertilization (significant in both site types; 


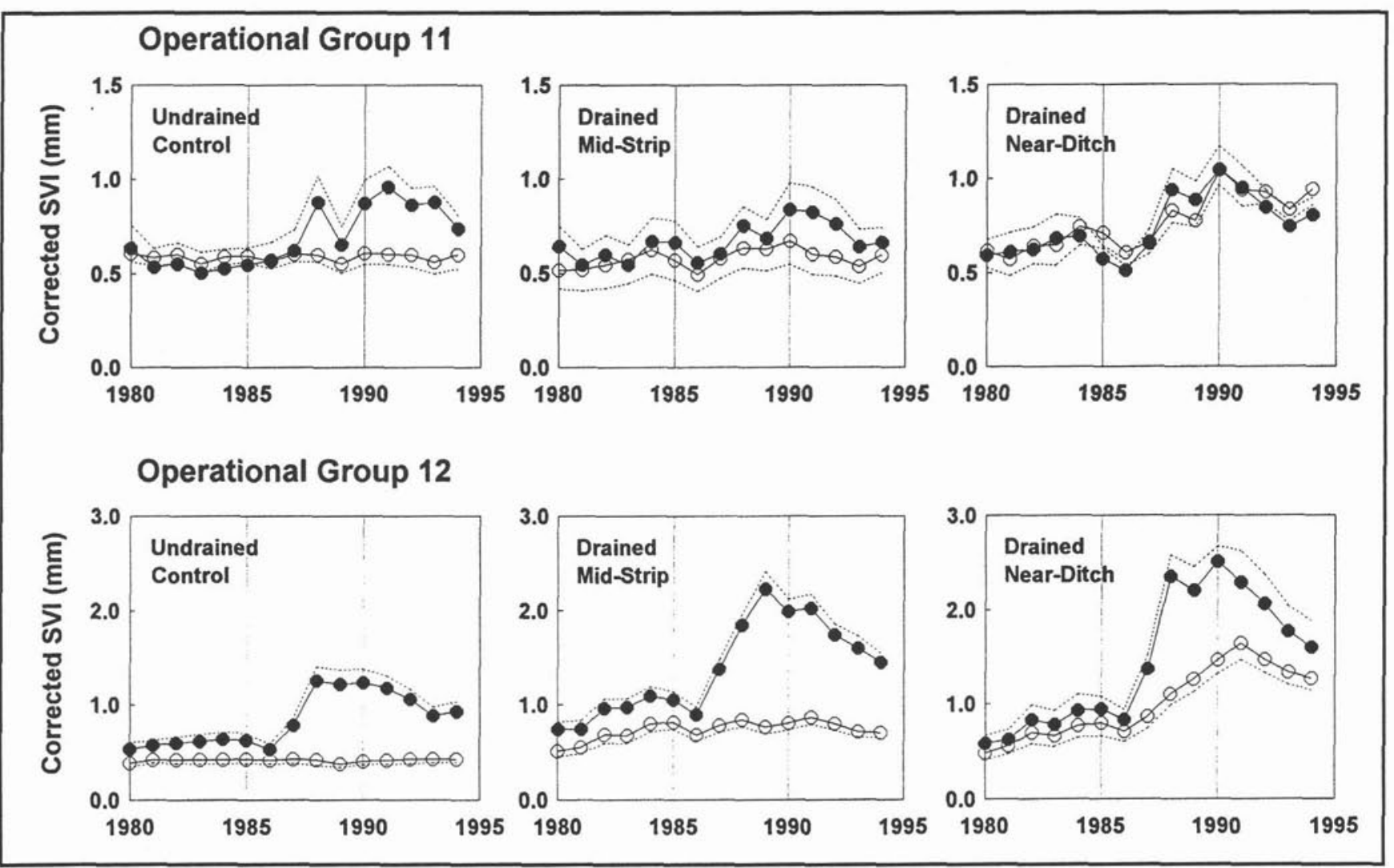

Fig. 4. Corrected annual SVI (mm), averaged for black spruce destructively sampled in 2 size classes, illustrated by operational site type and plot location relative to drainage. Unfertilized (open circles) and fertilized growth (filled circles) are compared in the same graphs. Annual SVI for dominant-codominant and intermediate trees were not different, so they were combined in the figure. Vertical lines separate three treatment periods (cf. Fig. 3). Lower dotted line is the lower standard error for unfertilized trees $(n=10)$ and upper dotted line is the upper standard error for fertilized trees $(n=10)$. SVI correction is based on the average annual deviation from mean SVI for all control, unfertilized trees $(n=10)$ in each site type for the entire 15-year period. Note the scale change between site types.

Tables 4, 5). There was a slight (non-significant) increase in $\mathrm{N}$ with drainage in OG 12 , and the fertilization enhancement in $\mathrm{P}$ was somewhat balanced by a (non-significant) decrease measured when comparing drained to undrained plots in OG12 (Table 4).

\section{Discussion}

Growth and yield responses in the first five-year, post-treatment period to fertilization are consistent with previous assessments (Sundström 1992a, 1992b) and with the results of other studies, where fertilization effects can occur within the first one to five years in black spruce (Weetman 1968, 1971, 1975; Morrison and Foster 1979; Foster et al. 1986; Weetman et al. 1972, 1995). However, when one is considering only drainage, the response is slower, with significant differences in this study occurring mainly in the second, five-year, posttreatment period (Table 2, Fig. 3).

As expected, individual tree response in OG 11 is smaller, and improvements in this type are a function of smaller increment increases for higher tree densities than OG 12. Tree growth response in OG 11 during both the first (one- to five-year) and second (six-to ten-year) post-treatment periods is smaller than in OG 12 (Fig. 4). Yield calculations based on plot density measurements in OG 11 show a significant total response, but only when the treatments are applied in combination (Table 3, Fig. 5).
In contrast, trees in OG 12 respond earlier to fertilization, resulting in a longer duration of total response to treatments that is roughly equivalent in both size classes (Fig. 3). In this type, growth response begins early in fertilized plots, and starts to decline five years following treatment (Fig. 4), but is equivalent to a remarkable $200 \%$ yield improvement when drainage and fertilization are applied in combination (Fig. 5). Considerable variation exists for tree density in OG 12 , which is lower overall than in OG 11 (Table 1), resulting in unpredictable results in terms of total yield improvement (Table 3).

In both OG 11 and OG 12 site types, the largest foliar macronutrient increase was by $\mathrm{P}$, suggesting that this element may be generally most limiting in boreal peatland systems (Mugasha et al. 1991, 1993; Hökkä et al. 1996), or that improvements due to fertilization were more prolonged for this element than for N or K (Weetman 1971, 1975; Foster et al. 1986; Weetman et al. 1995; Wells and Warren 1997). The slightly higher uptake of $\mathrm{N}$ by trees in drained versus undrained $\mathrm{OG}$ 12 plots may be a result of increased levels available to roots in deeper peat, once drainage resulted in peat subsidence, increased bulk densities, and higher rates of mineralization. Laiho and Laine (1994) show that this effect can last more than 55 years in drained peatland in Finland. It is unclear why, for drainage alone, improved nutrient uptake was slight, and limited to $\mathrm{N}$ and to OG 12 in this study, nor why drainage reduced $P$ 

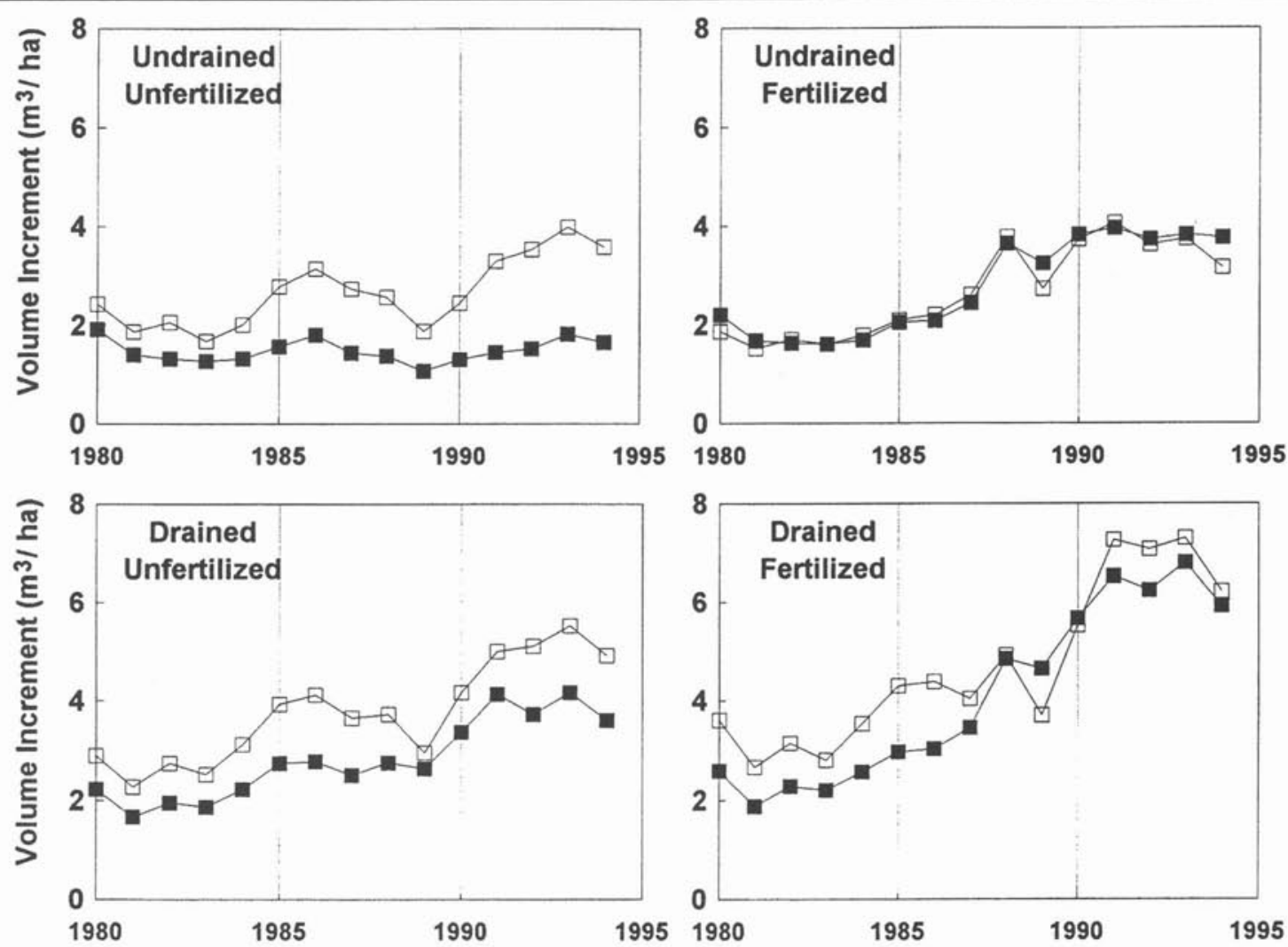

Fig. 5. Annual volume increment $\left(\mathrm{m}^{3} \mathrm{ha}^{-1}\right)$, for four treatments in three periods (separated by vertical lines, cf. Fig. 3), and two operational site types, OG 11 (open squares) and OG 12 (filled squares). Increment is based on mean for destructively sampled black spruce trees multiplied by mean 1994 tree density measured separately in undrained control, drained mid-strip (DM) and drained near-ditch (DN) subplots for the 2 site types (Table 1). Results for drained treatments were summed across the DM and DN subplots.

Table 4. Needle mass and foliar nutrient concentrations for current-year (1995) black spruce foliage, from dominant-codominant trees in undrained, unfertilized (UU), undrained, fertilized (UF), drained, unfertilized (DU), and drained, fertilized (DF) plots in the Wally Creek area. See Table 5 for statistical comparison of these results

\begin{tabular}{|c|c|c|c|c|c|c|c|c|}
\hline \multirow[b]{2}{*}{ Treatment } & \multicolumn{4}{|c|}{ Operational Group 11} & \multicolumn{4}{|c|}{ Operational Group 12} \\
\hline & UU & UF & DU & DF & UU & UF & DU & DF \\
\hline Mass ( $\mathrm{g} / 100$ needles) & 0.18 & 0.19 & 0.19 & 0.19 & 0.15 & 0.20 & 0.17 & 0.20 \\
\hline Nitrogen, N (\%) & 1.05 & 1.04 & 1.05 & 1.07 & 1.03 & 1.05 & 1.08 . & 1.15 \\
\hline Phosphorus, P (\%) & 0.14 & 0.21 & 0.14 & 0.21 & 0.14 & 0.22 & 0.14 & 0.19 \\
\hline Potassium, K (\%) & 0.47 & 0.44 & 0.48 & 0.51 & 0.46 & 0.48 & 0.43 & 0.49 \\
\hline Calcium, $\mathrm{Ca}(\%)$ & 0.53 & 0.53 & 0.39 & 0.43 & 0.43 & 0.37 & 0.50 & 0.37 \\
\hline Magnesium, $\mathrm{Mg}$ (ppm) & 0.15 & 0.16 & 0.14 & 0.13 & 0.14 & 0.13 & 0.15 & 0.13 \\
\hline
\end{tabular}

uptake in OG 12. The latter effect may have occurred because of increased mineral binding with $\mathrm{P}$ (Laiho and Laine 1995).

Deficiency and optimal levels for $\mathrm{N}, \mathrm{P}$, and $\mathrm{K}$ for black spruce are $1.20 \%$ and $1.50 \%, 0.14 \%$ and $0.18 \%$, and $0.30 \%$ and $0.40 \%$ (Swan 1970). In this study, the N effect associated with the treatments still left trees at deficient levels, similar to levels reported elsewhere for peatlands (Weetman 1968; Wells 1994; Wells and Warren 1997). In contrast, P concentrations even in undrained, unfertilized foliage were above deficiency levels, and experienced substantial increases with drainage and fertilization, that are comparable to other reports (Wells 1994), but with a longer duration of response. No deficient levels were recorded for $\mathrm{K}$ in this study. Deficiency and optimal levels for $\mathrm{Mg}$ and $\mathrm{Ca}$ are $0.10 \%$ and $0.15 \%$, and $0.09 \%$ and $0.12 \%$ (Swan 1970). Magnesium and calcium declined to below optimal levels in drained plots in OG 11, and $\mathrm{Mg}$ declined slightly in fertilized plots in OG 12 . It is possible that these elements were removed from the soil by leaching during the ten years since drainage (Laiho and Laine 1995).

This study documents the yield improvements associated with drainage and fertilization investments during a ten-year response period in black spruce peatland. The calculations presented in this paper, in comparison to results from other recent peatland drainage projects (Payandeh 1973a; Dang and Lieffers 1989; Mugasha et al. 1993), additionally show 
Table 5. Split-plot analysis of variance (MANOVA) table showing F-ratios and associated probability limits $\left({ }^{*} p<0.05\right.$, ** $\left.p<0.0001\right)$ for the effects of drainage, $D$, fertilization, $F$, and their interaction, $D \times F$, in the needle analyses (Table 4)

\begin{tabular}{lcccccc}
\hline & \multicolumn{3}{c}{ OG 11 } & \multicolumn{3}{c}{ OG 12 } \\
\cline { 2 - 7 } Treatment & $\mathbf{D}$ & $\mathbf{F}$ & $\mathbf{D} \times \mathbf{F}$ & $\mathbf{D}$ & $\mathbf{F}$ & $\mathbf{D} \times \mathbf{F}$ \\
\hline Mass (g/100 needles) & 0.01 & 0.48 & 0.39 & 0.64 & 7.16 & 0.14 \\
Nitrogen, N (\%) & 0.30 & 0.06 & 0.13 & 4.74 & $* * 117.38$ & 0.48 \\
Phosphorus, P (\%) & 0.03 & $* * 94.74$ & 0.08 & 0.29 & 5.69 & 1.44 \\
Potassium, K (\%) & 2.28 & 0.00 & 1.37 & 0.57 & 4.06 & 0.42 \\
Calcium, Ca (\%) & $* 9.96$ & 0.42 & 0.26 & 0.01 & 3.38 & 0.27 \\
Magnesium, Mg (ppm) & $* 6.60$ & 0.01 & 0.62 &
\end{tabular}

medium-scale spatial and temporal response to drainage and fertilization. Although total yield estimates on a plot basis from OG 11 and OG 12 site types in the improved Wally Creek area are similar late in the post-treatment period, yield improvements on a per-tree basis come earlier and reach higher (although more variable) levels in OG 12. Drainage should not be considered without fertilization and/or increasing available nutrients by thinning (Hökka et al. 1996; Saarinen 1996), because the treatments in combination appear to produce effective improvements.

This study cannot endorse the environmental effects or economic advantages associated with wetland drainage, but it serves as a silvicultural benchmark for growth responses to drainage and fertilization, should intensive forest management become popular once again. Existing environmental monitoring for the Wally Creek area can be found in Berry (1991) and Berry and Jeglum (1991b). Further economic analysis is not in the scope of this paper, but could be investigated by comparing the implementation costs of the project, $\$ 275 \mathrm{ha}^{-1}$ in 1984 (Rosen 1989), to present market values of black spruce pulpwood. No costs were calculated for the fertilization trials, because manual applications were not intended as operational. The economic returns for this area could be recalculated and compared to previous analysis in Ontario's Claybelt (Payandeh 1973b), with the advantage that the results of the Wally Creek project are replicated within a systematic design.

\section{Acknowledgements}

Funding for this study came from the Lake Abitibi Model Forest and a U.S. Department of Agriculture McIntire-Stennis grant to Michigan Technological University (MTU). Due acknowledgements go to Mike Rosen and Andrew Mutchmor, Ontario Ministry of Natural Resources (OMNR), for their contribution in establishing the Wally Creek project, the staff of the Cochrane District, OMNR, for periodic maintenance and monitoring of the study site; W. R. Watt, OMNR, for the loan of the TRIM equipment; R. J. Miller, OMNR, for loan of the SAM software; and Kathy Holt, Edith Greene and Seth Maefsky, MTU, for increment core measurement, stem analyses and preparation of samples. Neil Foster and Joe Ramakers, Canadian Forest Service (CFS), carried out the foliar analyses. Henning Thien, Chris Schachow, Helmut Schachow and Peter Bonfield all deserve special thanks for field assistance. Fred Haavisto and Erik Sundström, formerly CFS, offered many useful discussions during the project. Doyle Wells, CFS, and two anonymous reviewers kindly improved on earlier drafts. The authors thank the Lake Abitibi Model Forest and AbitibiPrice Inc. for providing field accommodations and continued support in the Wally Creek project.

\section{References}

Averell, J. L. and P. C. McGrew. 1929. The reaction of swamp forests to drainage in northern Minnesota. Bull. Comm. Drainage and Waters, State of Minnesota.

Berry, G. J. 1991. Hydrology of drained and undrained black spruce peatlands: streamflow and hydrologic balance. Can.-Ont. For. Res. Dev. Agr. Report 3317.

Berry, G. J. and J. K. Jeglum. 1991a. Hydrology of drained and undrained black spruce peatlands: groundwater table profiles and fluctuations. Can.-Ont. For. Res. Dev. Agr. Report 3307.

Berry, G. J. and J. K. Jeglum. 1991b. Hydrology of drained and undrained black spruce peatlands: surface water and groundwater quality. Can.-Ont. For. Res. Dev. Agr. Report 3316.

Canadian Forest Service. 1995. Criteria and indicators for the sustainable management of temperate and boreal forests: The Montreal Process. Natural Resources Canada, Ottawa, ON.

Dang, Q. L. and V. J. Lieffers. 1989. Assessment patterns of response of tree ring growth of black spruce following peatland drainage. Can. J. For. Res. 19: 924-929.

Duff, G. H. and N. J. Nolan. 1957. Growth and morphogenesis in the Canadian forest species. II. Specific increments and their relation to the quantity and activity of growth in Pinus resinosa. Can. J. Bot. 35: 527-572.

Ecological Services for Planning, Ltd. 1985. Land resource surveys, peatland forest drainage project, Wally Creek area. Unpubl. Report. $51 \mathrm{pp}$.

Foster, N. W., I. K. Morrison and H. S. D. Swan. 1986. Growth response of a boreal black spruce stand to fertilizer treatments. North. J. Appl. For. 3: 142-144.

Haavisto, V.F. 1984. Peatland forest drainage in northern Ontario: a Finnish approach. Pp. 5-6 in C. A. Plexman (ed.) Forestry Newsletter. Dept. Environ., Can. For. Serv. Fall/Winter.

Haavisto, V. F. and J. K. Jeglum. 1991. Peatland potentially available for forestry in Canada. Pp. 30-37 in J. K. Jeglum and R. P. Overend (eds.) Symposium 1989 Peat and Peatlands: Diversification and Innovation, Vol. 1. Peatland Forestry. Québec, QC, 6-10 Aug. 1989.

Härkönen, E. 1986. Using Lännen S-10 for forest drainage. Proc. Can. Pulp Pap. Assoc. Annual Meeting, 28-29 Jan. 1986.

Heikurainen, L. 1964. Improvement of forest growth on poorly drained peat soils. Intl. Rev. of For. Res. 1: 39-113.

Heikurainen, L., and K. Kuusela. 1962. Revival of the tree growth after drainage and its dependence on the tree size and age. Comm. Inst. For. Fenn. 55(8).

Hillman, G. R. 1987. Improving wetlands for forestry in Canada. Can. For. Serv. North. For. Res. Cent. Info. Report NOR-X-288.

Hillman, G. R., J. D. Johnson and S. K. Takyi. 1990. The Canada-Alberta wetlands drainage and improvement for forestry program. Can. Alta. For. Res. Dev. Agr. Project \# 1413-1417-86.

Hökkä, H., T. Penttilä and B. Hånell. 1996. Effect of thinning on the foliar nutrient status of Scots pine stands on drained boreal peatlands. Can. J. For. Res. 26: 1577-1584.

Honer, T. G., M. F. Ker, and I. S. Alemdag. 1983. Metric timber tables for the commercial tree species of central and eastern Canada. 
Can. For. Serv. Info. Report M-X-140.

Jeglum, J. K. 1991a. Definition of trophic classes in wooded peatlands by means of vegetation types and plant indicators. Ann. Bot. Fennici 28: 175-192.

Jeglum, J. K. 1991b. The Wally Creek Area Forest Drainage Project in Ontario's claybelt: Progress report. Pp. 47-53 in J. K. Jeglum and R. P. Overend (eds.) Symposium 1989 Peat and Peatlands: Diversification and Innovation, Vol. 1. Peatland Forestry. Québec, QC, 6-10 Aug. 1989.

Jeglum, J. K. and Fangliang He. 1995. Pattern and vegetation-environment relationships in a boreal forested wetland in northeastern Ontario. Can. J. Bot. 73: 629-637.

Jones, R. K., G. Pierpont, G. M. Wickware, J. K. Jeglum, R. W. Arnup and J. M. Bowles. 1983. Field guide to forest ecosystem classification for the Clay Belt, Site Region 3E. Ontario Ministry of Natural Resources, Maple, ON. 123 pp.

Ketcheson, D. E. and J. K. Jeglum. 1972. Estimates of black spruce and peatland areas in Ontario. Can. For. Serv. Great Lakes For. Res. Cent. Info. Report O-X-172.

Laiho, R. and J. Laine. 1994. Nitrogen and phosphorus stores in peatlands drained for forestry in Finland. Scand. J. For. Res. 9: 251-260. Laiho, R. and J. Laine. 1995. Changes in mineral element concentrations in peat soils drained for forestry in Finland. Scand. J. For. Res. 10: 218-224.

Laine, J. and Starr, M. R. 1979. An analysis of the post-drainage stand increment in relation to the peatland site type classification in Finland. Pp. 147-159 in Proc. Intl. Symposium on Classification of Peat and Peatlands, Hyytiälä, Finland, 17-21 Sept. 1979.

LeBarron, R. K., and J. R. Netzel. 1942. Drainage of forested swamps. Ecology 23: 457-465.

MacLean, D. W. and G. H. D. Bedell. 1955. Northern Clay Belt growth and yield survey. Dept. Northern Affairs and Natural Resources Forest Research Division Technical Note No. 20.

McLaren, B. E. and J. K. Jeglum. 1995. Growth response during ten years following drainage at Wally Creek, Ontario. Pp. 125-133 in J. P. Skovsgaard and H. E. Burkhart (eds.) Recent advances in forest mensuration and growth and yield research. Proc. from 3 sessions of Subject Group S4.01 'Mensuration, Growth and Yield' at the 20th World Congress of IUFRO, held in Tampere, Finland, 6-12 August 1995. Danish For. and Landscape Res. Inst. 250 pp.

Morrison, I. K. and N. W. Foster. 1979. Five-year growth in two nitrogen-phosphorus fertilization experiments in spruce and spruce-fir upland forest in Northern Ontario. Great Lakes For. Res. Cent. Info. Report O-X-299.

Mugasha, A. G., D. J. Pluth, K. O. Higgenbotham and S. K. Takyi. 1991. Foliar responses of black spruce to thinning and fertilization on a drained shallow peat. Can. J. For. Res. 21: 152-163.

Mugasha, A. G., D. J. Pluth and G. R. Hillman. 1993. Foliar responses of tamarack and black spruce to drainage and fertilization of a minerotrophic peatland. Can. J. For. Res. 23: 166-180.

Päiväinen, J. 1984. Increasing the land base and yield through drainage. Proc. Ontario Ministry Natural Resources Info. Session, Timmins, ON. March 1984.

Päiväinen, J. and E. D. Wells. 1977. Guidelines for the development of peatland drainage systems for forestry in Newfoundland. Nfld. For. Res. Cent. St. John's NF. Info. Rep. N-X-156.

Payandeh, B. 1973a. Analyses of a forest drainage experiment in northern Ontario. I. Growth analysis. Can. J. For. Res. 3: 387-398.

Payandeh, B. 1973b. Analyses of a forest drainage experiment in northern Ontario. II. An economic analysis. Can. J. For. Res. 3: 399-408. Rosen, M. 1986. The installation of a systematic peatland drainage system for forestry. Pp. 201-209 in Proc. Advances in Peatlands Engineering. Natl. Res. Counc. Can., Ottawa, ON, 25-26 Aug. 1986.
Rosen, M. 1989. Forest drainage manual: an operational manual for the development of forest drainage projects in the province of Ontario. Ontario Ministry of Natural Resources Science and Technology Series, Vol. 3. 25 pp.

Rothwell, R. L. 1988. Substrate environments on drained and undrained peatlands, Wally Creek experimental drainage area, Cochrane, Ontario. Pp. 103-108 in Proc. IUFRO World Congress. Rothwell, R. L., U. Silins and G. R. Hillman. 1996. The effects of drainage on substrate water content at several forested Alberta peatlands. Can. J. For. Res. 26: 53-62.

Saarinen, M. 1996. Effects of the removal of shelterwood on the foliar nutrient concentrations of Norway spruce (Picea abies [L.] Karst.) on drained peatlands. Suo 47: 93-102.

Satterland, D. R. and S. A. Graham. 1957. Effects of drainage on tree growth in stagnant sphagnum bogs. Univ. Mich., Sch. Nat. Res., Ann Arbor. Research Note No. 19.

Stanek, W. 1968. A forest drainage experiment in northern Ontario. Pulp \& Paper Mag. Can. 69(18): 58-62.

Stanek, W. 1977. Ontario clay belt peatlands - are they suitable for forest drainage? Can. J. For. Res. 7: 656-665.

Sundström, E. 1992a. Five-year growth response in drained and fertilized black spruce peatlands. I. Permanent growth plot analysis. NEST Technical Report TR-02 / Forestry Canada Info. Report O-X-417. $19 \mathrm{pp}$.

Sundström, E. 1992b. Growth response of black spruce five years after drainage and fertilization in the Clay Belt of Northern Ontario, Canada. Pp. 434444 in Proc. 9th Int. Peat Congress, Uppsala, Sweden, 22-26 June 1992.

Sundström, E. and J. K. Jeglum. 1992. Five-year growth response in drained and fertilized black spruce peatlands. II. Stem analysis. NEST Technical Report TR-03/Forestry Canada Info. Report O-X-420. $13 \mathrm{pp}$.

Swan, H. S. D. 1970. Relationships between nutrient supply, growth and nutrient concentrations in the foliage of black spruce and jack pine. Pulp \& Paper Res. Inst. Can. Woodland Paper No. 19.

Trottier, F. 1984. Implementing forest drainage in Canada. Pp. 75-77 in Proc. of the CPPA/CFS Seminar on the Mechanization of Silviculture. 17 Sept. 1984, Thunder Bay, ON.

Weetman, G. F. 1968. The nitrogen fertilization of three black spruce stands. Pulp \& Paper Res. Inst. Can. Woodland Paper No. 6. Weetman, G. F. 1971. Effects of thinning and fertilization on the nutrient uptake, growth and wood quality of upland black spruce. Pulp \& Paper Res. Inst. Can. Woodland Paper No. 28.

Weetman, G. F. 1975. Ten-year growth response of black spruce to thinning and fertilization treatments. Can. J. For. Res. 5: 302-309. Weetman, G. F., R. Knowles and S. Hill. 1972. Effects of different forms of nitrogen fertilizer on nutrient uptake by black spruce and its humus and humus mesofauna. Pulp \& Paper Res. Inst. Can. Woodland Paper No. 39.

Weetman, G. F., L. C. Dallaire, and R. Fournier. 1995. Long-term effects of repeated $\mathrm{N}$ fertilization and straw application in a jack pine forest. 1. Twenty-two-year growth response. Can. J. For. Res. 25: 1978-1983.

Wells, E. D. 1994. Effects of planting spacing and refertilization on growth and nutrition of black spruce (Picea mariana (Mill.) B.S.P.) planted on a minerotrophic peatland in Newfoundland, Canada. Can. J. For. Res. 24: 1302-1311.

Wells, E. D. and W. G. Warren. 1997. Height growth, needle mass and needle nutrient concentrations of $\mathrm{N}, \mathrm{P}, \mathrm{K}, \mathrm{Ca}, \mathrm{Mg}$ and $\mathrm{Cu}$ in a 6-year-old black spruce peatland plantation in Newfoundland, Canada. Scand. J. For. Res. in press.

Zon, R., and J. L. Averell. 1929. Drainage of swamps and forest growth. Univ. Wisc. Agric. Exp. Sta. Res. Bull. 89. 